\title{
How game changers catalyzed, disrupted, and incentivized social innovation: three historical cases of nature conservation, assimilation, and women's rights
}

\author{
Frances R. Westley ${ }^{1,2}$, Katharine A. Mc Gowan $^{3}$, Nino Antadze $^{4}$, Jaclyn Blacklock $^{5}$ and Ola Tjornbo $^{1}$
}

\begin{abstract}
We explore the impact of "game changers" on the dynamics of innovation over time in three problem domains, that of wilderness protection, women's rights, and assimilation of indigenous children in Canada. Taking a specifically historical and crossscale approach, we look at one social innovation in each problem domain. We explore the origins and history of the development of the National Parks in the USA, the legalization of contraception in the USA and Canada, and the residential school system in Canada. Based on a comparison of these cases, we identify three kinds of game changers, those that catalyze social innovation, which we define as "seminal," those that disrupt the continuity of social innovation, which we label exogenous shocks, and those that provide opportunities for novel combinations and recombinations, which we label as endogamous game changers.
\end{abstract}

Key Words: complexity; game changers; innovation; North America; social innovation; transformative change

\section{INTRODUCTION}

A focus on social innovation as response to complex social challenges is on the rise in the public and academic arenas. In 2004, there were 815 articles that included the keyword social innovation; in 2012, this number has more than doubled to 1746 (SciVerse Scopus). Yet despite this interest, and despite the growing number of empirical case studies, many of the processes associated with social innovation remain anecdotal, ill defined, or unexplored (European Commission 2013). There is still need for systematic evaluations of empirical data geared to the creation of conceptual frameworks that allow for the cross-case analyses and have predictive power, in short theory building. (Howaldt et al. 2014)

We introduce a framework for studying social innovation that defines successful social innovation as any project, product, process, program, platform, or policy that challenges and, over time, changes, the defining routines, resource and authority flows, or beliefs of the broader social system in which it is introduced. Successful social innovations have durability, scale, and transformative impact (Westley et al. 2013). Our approach to social innovation draws on complexity theory, resilience theory, and structuration theory (Westley et al. 2006). As such it is linked to other emergent bodies or schools of research on social change and transformation including the socio-technical transition school (Markard et al. 2012, Raven et al. 2012, Geels 2014) and sustainability transitions work (Grin et al. 2010, Loorbach 2010, De Haan and Rotmans 2011). Our definition shares with those approaches an interest in the dynamics of social innovation as it unfolds over time and an explicitly cross-scale approach (cf. Kemp et al. 2007)

It differs, however, in the use of particular elements of the complexity theory lens to focus attention on such concepts as critical transitions, tipping points, the adjacent possible (Kauffman 2000, Scheffer et al. 2009), and the prophetic role of starting conditions (central concepts in complexity theory), as well as an explicit focus on the role of institutional or system entrepreneurs, as a key agent in system transformation. We see institutions as both constraining and enabling individual actors (agency), and as determining social action and being reshaped by it (Giddens 1984), and we are concerned with how agency interacts strategically with opportunity contexts (Dorado 2005, Olsson et al. 2006, Gelcich et al. 2010, Westley et al. 2013), to accelerate such transformation by "scaling up" social innovation (Moore et al. 2015).

In addition, for purposes of this paper, we will focus on the relatively new concept of "game changers" and their impact on the dynamics of social innovation. Game changers are broadly conceptualized as "macro-phenomena (events and trends) that are perceived to change (the rules, fields and players in the) the 'game' of societal interaction. The dominant understandings, values, institutions and social relationships through which society is organised and defined may fundamentally change in response to game-changing events and trends. The purpose of this 'gamechanger' notion is to explore how empirical macro-phenomena are perceived as 'game-changing' - how they are interpreted, (re) constructed, contested and dealt with - by people and initiatives working on transformative social innovation" (Avelino et al. 2014:2-3).

There is clearly some overlap between our definition of social innovation and that of "game changer," particularly because they meet in the concept of a fundamental shift in values, institutions, and social relationships. Game changers, however, are defined as macro-phenomena (events and trends) that are endogenous to the activity of the agents involved in social innovation. In an effort to increase conceptual clarity, therefore, for purposes of this paper we will treat game changers as a key aspect of opportunity context (Dorado 2005, Olsson et al. 2006, Gelcich et al. 2010, Westley et al. 2013); shifts in institutions at one scale can allow for new ideas, programs, projects to get traction and secure resources needed for further transformation. We will explore how different kinds of game changers are used by social innovators to affect the trajectory of their innovation work.

${ }^{1}$ Waterloo Institute for Social Innovation and Resilience, University of Waterloo, ${ }^{2}$ School for Environment, Enterprise and Development, University of Waterloo, ${ }^{3}$ Bissett School of Business, Mount Royal College, Calgary, Alberta, ${ }^{4}$ Department of Environmental Studies, Bucknell University, ${ }^{5}$ University of Waterloo 
We will explore three problem domains: the challenge of conserving a disappearing wilderness in the U.S., the challenge of women's rights relative to birth control and contraception, and the challenge of the indigenous-colonial relationship in Canada. We will look more closely at three transformative initiatives within these domains: the creation of a national park system in the U. S., the legalization of contraception, and the creation of the residential schools, to explore their antecedents and their consequences from a historical perspective. We will identify three categories of game changers, the role of agency, the role of the "adjacent possible," and the prophetic role of the starting conditions in these three different cases. We will begin with a discussion of the methodological challenges of historical studies of complex adaptive systems and we will conclude with insights regarding game changers and social innovation garnered from exploring history through a complexity lens.

Note that our definition of social innovation does not assume the positive value of any particular innovation. Instead it focuses on a set of dynamics and of strategies, both deliberate and emergent, that characterize the transformation of a complex adaptive system. History may judge that transformation positively or negatively (as history has judged the residential schools in Canada). We see social innovation as a process that requires constant reassessment and ethical vigilance: as social innovators increase their effectiveness, so they must also be alert to the almost inevitable negative consequences of social innovation.

\section{METHODOLOGICAL CONSIDERATIONS}

\section{The argument for historical cases in theory building}

According to Plummer and Fennell (2007), there are four general avenues for theory building: modeling schemes (wherein a visual representation of the phenomenon or relationship is created), propositional schemes (statements about the relationships between two or more variables), analytical schemes (defining key properties of the universe), and meta-theoretical schemes (explanations of underlying assumptions associated with the phenomena in question). Meta-theoretical schemes are still in short supply in the social innovation field (Nicholls et al. 2015)

Using an historical approach, however, we see the potential to build toward a more complete theoretical understanding, a metatheory according to Plummer and Fennell's categorization. This meta-theory will not only inform academic inquiry into the increasingly important phenomenon of social innovation, but will also serve as the basis for a meaningful set of evaluation criteria for real-life innovations and innovators. Specific objectives of such a research program are to (1) identify and characterize empirical cases of social innovation, (2) complete cross-case comparisons to derive knowledge on social innovation trajectories and to identify common mechanisms at work in social innovation processes in a range of different social and historical contexts, and (3) generate a set of testable hypotheses based on these observations that may be examined retroactively or proactively in the light of other empirical data.

Historical approaches are particularly promising in the study of complex systems. In such systems, information and behaviors do not necessarily and easily scale up because the micro-level does not simply add up to produce outcomes at the macro level and one does not explain the other. For this reason, such systems pose particular challenges for conventional sociological methodologies (Homer-Dixon 1996). Confronted with complex systems scholars have noted the utility of comparisons across several empirically rich, detailed case studies (Young et al. 2006). Additionally, history is an excellent medium to examine complex systems, for although these systems may be difficult or impossible to predict, "historically we can see what happened" (Byrne 1998:26, and see also Mumford and Moertl 2003).

In a seminal work on the nature of technology, Brian Arthur (2009) used complexity theory to explore the historical dynamics of the emergence of new technologies. He suggested that new technologies and technological domains emerge as the result of the discovery of new naturalistic phenomena, as well as through the combination of existing technologies within and across adjacent domains, a version of Kauffman's (2000) notion of adjacent possible. Combination is commonly acknowledged as a key mechanism in both technological invention and scientific discovery (van den End and Kemp 1999, Becker et al. 2006, Arthur 2009, Biggs et al. 2010, Thagard 2012).

Does social innovation share a similar dynamic with technological innovation? Clearly not all social innovation is driven by the discovery of new scientific phenomena. Although naturalistic phenomena of the kind identified by Arthur (2009), such as scientific discoveries of biological and chemical processes, may play some role, shifting our understanding of human biology or behavior, constructed phenomena are equally key. These are ideas, often value laden, that a discrete group (a culture, a sect, a political group) believes to be true and that guide their behavior accordingly. These "social facts" may not be seen or studied directly because they are not tangible, but they are real in their effects, and constrain or direct our activities (Durkheim 1912, 1968). Technological phenomena are a third category. Although we recognize, with Arthur, that technologies themselves are likely to be founded on naturalistic phenomena, once in the world, such technologies themselves may stimulate social innovation; indeed they may become game changers.

Following Arthur's theory, we trace our social innovations back to one of these types of new phenomena that create the intellectual space for clusters of inventions, including social inventions. The process by which social inventions become social innovations is, like technological innovations, tied to the pattern of available combinations, but they are also tied to the opportunity context (Westley et al. 2013) in which they arise, a context that is shaped by game changers. As noted above, we accept the definition of game changers as macro-trends that are perceived to change the rules of the game, i.e., to change how society is organized and defined by today's understandings, values, institutions and social relationships (Avelino et al. 2014), but we will argue that in addition to trends, game changers may be discrete critical moments that provide windows of opportunity, that there is a discernable pattern in the kind of opportunities important for social innovation.

In sum, by looking at well-known and studied historical cases, scholars can gain access to very detailed accounts of social innovations, an access that facilitates comparison across cases with a common set of observable features. But there is a risk of overemphasizing detail, context, and specificity, and of imposing rigid theory on the messy complexity of human systems. To solve 
the tension between the unique and the rule, and be able to travel between the micro, meso, and macro scales and see relevant connections between them, this program of study employs an exploratory approach informed by Charles Tilly's discussion of a mechanism-process model research program. In this approach, the researcher seeks to identify common "robust mechanisms" acting within the local contexts of each case. These mechanisms work within and between local circumstances, and produce a result that reflects that mutual imprinting, so that the same mechanism does not produce identical results across cases (Tilly 2008).

In its insistence on sampling across scales, this approach has a nice fit with recent work on social transformation, studies of transitions (Geels and Schot 2007, Rotmans and Loorbach 2010), and social-ecological transformations (Walker and Meyers 2004, Olsson et al. 2006). It follows Arthur (2009), however, in seeking to combine a long historical approach focusing on originating phenomena with a complex adaptive system approach in order to explore the dynamics of innovation over time.

To select our cases, we essentially started at the end. We began where the ultimate institutional impact was clear (the securing of major resources, legislation, wide spread cultural assimilation) and to work back through time, using secondary sources to try to uncover which phenomena (technical, natural, social) seem to have catalyzed the innovation. We then charted the pattern of evolution through time moving from microanalysis of the action of agents, monitoring the presence of individuals clearly associated with the innovation whether in a creative, supportive, or oppositional role, to a meso-scale focus on the problem domain and finally to a broader consideration of the shifting global landscape in which these domains evolved including major political, cultural, social, economic events occurring at the institutional and global scale.

This methodology revealed an interesting pattern of continuities and discontinuities. For example we would see smooth increases in activity around an innovation punctuated by absence of activity for a period of time and then a sudden reappearance of activity, this time with a different pattern. Based on the critical transition points we then did a second round of research that we termed "deep dives" where we would focus attention on a limited period and look for more qualitative and anecdotal evidence (news stories, court records, diaries) to understand the particular cultural, economic, intellectual, and political dynamics that characterized that period.

These three cases have been chosen because of their North American bias and because they each point to interesting hypotheses about the dynamic relationship between social innovation and game changers. As mentioned above, history (to date) has generally viewed two of these social innovations as positive, or at least progressive. The third, however, yielded tragic consequences and has been viewed retrospectively as ill conceived if not evil.

\section{THE CASES}

\section{National parks}

In the U.S., the national parks have become a cornerstone of modern conservation policy and have helped to redefine people's relationship to nature. Though they originated in a romantic, perhaps naive view of nature, the National Parks System is today a powerful and well-organized actor in the environmental movement. This case looks particularly at the role that individual agents played in turning a romantic idea into a concrete and institutionalized reality.

Although royal game preserves and city parks predated them, the founding of the National Park System in the U.S. was a social innovation that profoundly impacted the social-ecological system in North America. The first protected area, Yosemite, was created in 1864. With the country torn apart by the Civil War, the U.S. Senate passed a bill to dedicate a large area of land in California including Yosemite Valley and the Mariposa Grove of Big Trees for preservation and enjoyment of everyone. It passed without much deliberation and questioning and was later signed by President Abraham Lincoln (Duncan 2009). In 1872, President Ulysses S. Grant signed a bill to create Yellowstone Park. In contrast to Yosemite, Yellowstone was not managed on the state level, but on the federal one (Duncan 2009). A combination of colonist/economic, scientific, and romantic interests intertwined and with the help of key agents resulted in the preservation over the next 100 years of protected areas spanning 2,607,131 km $(1,006,619$ sq. mi), or $27.08 \%$ of the land area of the United States. In Canada National Parks currently cover an area of $303,571 \mathrm{~km}^{2}$, or about $3.0 \%$ of the total land area.

\section{Legalization of contraception}

Contraception and a woman's right to choose remain highly contentious issues in modern societies all over the globe. At the end of the 19th century, what had before been the largely unregulated world of contraceptives, driven by market demand, was stopped in its tracks by religious opposition. Religious fervor drove powerful opponents to criminalize the use of contraception and for a time destroy supply, if not demand.

Proponents of the idea of woman's right to choose had to find other allies to move this innovation forward. This case considers how a social innovation, which originated in a social philosophy that argued for the equality of men and women, drew support from developments in adjacent domains. Those looking to transform the rights of women associated access to contraceptives with both new medical research into contraception and a growing concern about population and poverty. This combinatorial alchemy crystalized in the new idea of reproductive freedom. This initiative throughout faced religious opposition, and this case shows how conflict can drive combination and recombination in social innovation.

\section{Residential schools}

Not all social innovations have a positive impact, despite the best intentions of those involved in creating them. Residential schools were born out of a desire to tackle deep social issues affecting First Nations in Canada but became instead a tool of discrimination and terrible abuse that scarred multiple generations. From the mid-19th century until 1998, the Canadian government and religious authorities ran schools to Christianize and Canadianize indigenous children, and from 1880 onward, this effort took the form of Indian residential schools. Indian residential schools sit closer to social engineering than social innovation on a spectrum of agent-driven social change. Yet, if we understand social innovations as trying to target isolated or disadvantaged populations, to improve their standard of living and shift their outcomes, than residential schools certainly 
warrant consideration. The residential school experiment is a cautionary tale, of how attempts at social innovation can be fatally flawed and eventually fall out of favor when new ideas (social phenomena) emerge and unseat our current assumptions and beliefs. Nonetheless, this case also points to the sometimesperverse impact of dysfunction: spectacular failures can open the door to new and more positive opportunities.

\section{ANALYSIS: GAME CHANGERS AND SOCIAL INNOVATION}

As noted above, Avelino et al. (2014) see the value of the concept of game changer as providing a focal point for debate, interpretation, and social construction among those working toward a particular social transformation. When viewed historically, therefore, game-changing events mark, for the researcher, a kind of station on the journey of transformation, moments when we can probe the changing definitions and directions the transformation is assuming. Exploring these cases using the concept of game changer, three distinctive but related types of opportunity appear to be at work.

\section{Game changers as seminal ideas: the role of collective sense making in social innovation.}

Brian Arthur (2009) defines phenomena as aspects of the natural world that are discovered by science, and argues that these set in motion an emergent fountain of combining and recombining innovations that define new innovation space. As noted above, we have expanded his definition in the realm of the social to include "social facts," new ideas that in themselves have the power to shape behavior, as well as scientific breakthroughs and technologies that open the space for innovation. Interestingly, our project has pointed to a particularly powerful role in social innovation for these "social facts." Although undoubtedly, scientific insights into the human body, mind, and social behavior have had a role in all three of the innovations that are the focus of this paper, the most powerful drivers have been new ideas, social and political philosophies, often originating in the work of individual thinkers, which become schools of thought. Although these originating ideas are generally hotly contested and may take a number of years to form into a new school of thought, when they do, they offer a clear bifurcation with past dominant ideologies, offering, similar to Arthur's scientific breakthrough, a philosophical breakthrough that precipitates a cascade of transformative activity including philosophical debates, new organizations, and new programs.

In the case of the national parks, the underlying impetus can be found in the Romantic tradition. Romanticism and romantic environmentalism originated in Europe by the end of the 18th century and reached its climax during 1800-1850, partly in reaction to the industrial revolution and scientific rationalization of nature. As Jones (2012:34) notes, romanticism "advanced the worship of the wild." This was most visible in England, a country that served both as a cradle of industrialization, but also as a birthplace of the strongest opposition toward it. Rapid industrialization and urbanization of the 19th century transformed not only towns, but also the quiet English countryside. These changes fueled negative reactions, especially within the artistic circles (Guha 2000).
From the poets the strongest opposition was voiced by William Wordsworth who wrote the following:

\section{For I have learned}

To look on nature, not as in the hour

Of thoughtless youth; but hearing oftentimes

The still, sad music of humanity.

John Ruskin, an artist, art critic, art patron, and an influential thinker of his time, echoed Wordsworth poetic sentiments. Ruskin wrote that every river in England was polluted and turned "into a common sewer, so that you cannot so much as baptize an English baby but with filth, unless you hold its face out in the rain, and even that falls dirty" (as cited in Guha 2000:13). He believed that the modern man has desacralized nature by viewing and treating it only as a source of raw material and not finding the divinity in it that the premodern man saw (Guha 2000). Ruskin wrote, "Nature is painting for us, day after day, pictures of infinite beauty if only we have the eyes to see them."

The first recorded idea about the concept of national park belonged to the artist George Catlin (Jones 2012) who described it as a place "containing man and beast, in all the wild and freshness of their nature's beauty" (Duncan 2009:11). In 1832, after studying and observing the Indians and their environment on the Great Plains in South Dakota, Catlin was struck by the idea that this pristine wilderness, including the native Indians and their way of living, would be gone forever (Miles 1995, Duncan 2009). Catlin's ideas and aspiration to preserve the natural beauty in the face of destructive human activities fall squarely within the Romantic tradition.

In the case of legalization of contraception, the notion of human rights began in Europe in the late 18th and early 19th century, fuelled in part by the French Revolution. Early feminist philosophers such as the French playwright and political activist Olympe de Gouges used this game changer in 1789 to link the rights of women to that of human rights, generally assumed to be the rights of men, which were a central political and social debate in the Enlightenment (Phillips 2004). A key breakthrough came in 1869 when the influential philosopher and Member of Parliament, John Stuart Mill published his essay entitled "The Subjection of Women." He argued for the near slave status of married women and for the right to vote. Although his arguments won little support among contemporaries, they generated greater attention for the issue of women's suffrage (Van Wingerden 1999).

Although contraception was initially based on a naturalistic phenomenon, the discovery and understanding of human reproduction, and fueled by a technological game changer, the discovery of rubber and the invention of the condom, it was stopped in its tracks by Christian religious fervor, reaching its apex in the Comstock Act of 1873, which declared all forms of contraception "obscene" and akin to abortion. In response, beginning in 1910 a campaign to overturn the Comstock Act was launched by social entrepreneurs Emma Goldman, Mary Ware Dennett, and Margaret Sanger (Parry 2011). This marked the beginning of the birth control movement, associated explicitly with women's sexual liberation and gender equality, spearheaded by Margaret Sanger (Tone 1996). 
When the phenomena of the equality of men and women was linked to the idea of control of contraception, it also flew in the face of another "social fact," the religious belief of the evil of women who lured Adam into eating of the tree of knowledge and therefore insured that they were banned from paradise. The sexuality of women in a number of Christian traditions has always been seen as suspect, and the punishment of women for the sins of Eve has been suffering the pain of childbirth (aptly called labor). As we will see below, the clash between these two beliefs created not only a seminal moment of conflict but also a continued social tension that helps to explain the particular pattern of combination and recombination associated with this innovation.

In relationship to the residential schools, the game changers were also cultural ideas, and two important ones may be identified. The disregard or outright hostility for other cultures, especially non-European ones, was long standing. It was one of the covering assumptions in the settlement of North America that excused treaty breaking, and missionaries' work to "civilize" the populations of North America. This included individual schools as early as the 17 th century, although not as a continuous or cohesive organization (Miller 1996). These behaviors, and eventually policies of Canada and the United States were informed by the constructed social phenomena that human societies were hierarchically organized, from the most civilized to the most savage, and the belief that Christianity was a moral truth (the one true faith) that must be disseminated and must dominate (Castellano et al. 2008). Anglo-American and Anglo-Canadian society, as Christian and as Western, was therefore entitled and obligated to change ("civilize") indigenous peoples.

Nations must constantly build and rebuild themselves; they must train their new members in the rules, expectations, and opportunities. Public schools are one of the key institutions in this process in the modern era, as national systems devoted to training up children into "citizens for an industrial economy" (Jarman 1951). In the 19th century, at the same time as the residential schools' creation, schooling generally, that is, in common public schools, rather than elite institutions, was "hailed as a means of ending poverty, providing equality of opportunity, and increasing the national wealth" (Spring 2008:7) because schools could train children for their moral (religious), civic, patriotic, and industrial futures (Jarman 1951). Regardless if the pupils were young Englishmen to be sent to fight for Empire, or young indigenous children their teachers hoped to convert to Christian Canadians (Haig-Brown 1988), schooling was (and is) the popularly agreed-upon pathway from (relative) tabula rasa to desired outcome.

Indian residential schools (IRS) were an example of bricolage, the nexus of ideas about children and the nation-state and even humanity. Residential schools represented the culmination of the state's belief in its ability to shape its subjects through schooling, and that indigenous society and people needed to be changed. J. R. Miller argued that these schools "typified the totalitarian and assimilative spirit of Canada's Indian policy," at the time, with the simply stated (but not easily achieved) goal to "educate and colonize a people against their will." (Miller 1990:396).

Interestingly, these colonial ideologies met with less resistance than might be expected because of a shift in ideation among indigenous leaders, who, cognizant of the inexorable march of white civilization, came to see that their youth needed a different kind of education. The Garden River Ojibwa chief Augustine Shingwauk explained his rationale to the Anglican authorities in Toronto in 1871:

\section{I hoped that before I died I should see a big teaching wigwam built at Garden River, where children from the Great Chippeway Lake would be received and clothed, and fed, and taught how to read and how to write; and also how to farm and build houses, and make clothing; so that by and bye they might go back and teach their own people. (Miller 1996:5-6)}

Chief Shingwauk's teaching wigwams were to be a bridge between his people and a survivable future. This realization came at different times to indigenous nations across the continent, as Euro-Canadian settlers grew in number and the federal government sought to enforce its authority across the lands it claimed; this required adaptation and innovation for survival (Miller 1996) Importantly, the teaching wigwam was not a pathway out of traditional life and identity, but an effort to maintain those in a new world. Advocating for this pathway required a basic shift in perspective, that placed indigenous peoples in a Canadian, rather than indigenous context. It opened the door to residential schools as an innovation.

\section{Game changers as exogenous disturbances: the role of global crises and events in social innovation}

Although phenomena that stimulate abrupt changes in the pattern of social innovation can be seen as game changers, one of the interesting things about following multiple transformative social innovations over time is that it allows the researcher to see the impact of certain exogenous events across multiple domains. These events act as disturbances, creating opportunities for shifting institutional arrangements at the highest levels. It is notable that in our three cases, the World Wars, particularly the Second World War, had an impact on all three problem domains, but that impact was different in each problem domain.

In the case of the residential schools, the horror of the Holocaust shone a spotlight on the destructiveness of racially based policies that sought to eradicate racial difference through assimilation or separation/apartheid. There had been plenty of evidence that the residential schools were killing aboriginal children, as opposed to helping them. In 1907, Dr. Peter Bryce, then medical director for the Department of Indian Affairs, submitted a report he entitled "The Story of a National Crime" in which he estimated that up to $50 \%$ of aboriginal children died in the first year of attendance at a residential school (largely from tuberculosis). This report was suppressed and not published until 1922, after Bryce was relieved of his duties, but the publication did little to awake the collective conscience of a nation. On the other hand, the Holocaust, with its systematic elimination of six million Jews represented such a horrifying extreme, that it was impossible to condone policies that smacked of similar racial cleansing. Between 1948 and 1952 laws were passed to end the compulsory education of aboriginal children, although the last residential schools did not close until the 1970s. For this case, the Second World War represented a tipping point: it was a political/military event, but it was a cultural game changer. 
In the case of legalization of contraception, the outbreak of venereal disease among the troops in WWI opened the door for the legal distribution of condoms and for the first physician-run clinics for their distribution. This was also a major breakthrough for those fighting for the legalization of contraception. The war acted as a game changer in that it encouraged new medical practices and those interested in the legalization of contraception were able to "piggy back" on this institutional shift.

National parks as an innovation was stalled as opposed to augmented by war. Park creation was a peacetime activity. Between the end of the Spanish American War and the beginning of WWII, a pattern of proliferation can be seen with multiple parks created in the park system in the U.S. But in times of war, the focus became on security and on raw materials needed for the production of military equipment. Interestingly it was also a game changer of a cultural/perceptual nature. In the peacetime that has followed WWII, there has been a slowdown in the creation of new parks, but an increase in the administrative infrastructure that ensures their long run viability. Protection of the rare and precious has become the theme.

\section{The expansion of the NPS and development of new parks in Hawai' $i$ and elsewhere was also an outcome of the war. Engendered by an at least century-old faith in nature's transcendent values and by a growing recognition that the world was a [sic] both a finite and fragile place, the country's newfound awareness of the beauty and significance of the outdoors led, in turn, to a more profound commitment to preserving what remained of a shared inheritance. World War II may have unleashed unprecedented forces of devastation but it also ushered in a newfound respect for the natural environment and its importance to human existence. (Chapman 2014:411)}

When looking across the pattern of thresholds and discontinuities, game changers both universal and regime specific are clear punctuation marks, after which we see a change in pattern.

Game changers as endogamous opportunities: the role of conflict, agency, and the adjacent possible in the dynamics of social innovation

Although exogenous opportunities present windows that can be strategically used to advance, de-escalate, or redefine a social innovation, other game changing moments seem to be engineered by opposition to a trajectory of a particular social transformation, or by resource scarcity among those attempting to forward a social innovation. So although exogenous opportunities disturb the social architecture sufficiently to allow new ideas to get a purchase, endogamous opportunities are often deliberately and strategically constructed, most often through the development of necessary partnerships (Brown et al. 2013, Westley et al. 2013). These partnerships, however, have a tendency to shift the innovation space, occasionally resulting in an uneasy pairing of ideas.

The concept of "adjacent possible" was introduced by complexity theorist Stuart Kauffman (2000). He used the concept to point to the proximate elements in any situation with which a focal element may combine. Johnson (2010) makes a specific link between the concept and innovation. The phrase (adjacent possible) captures both the limits and the creative potential of change and innovation. In the case of prebiotic chemistry, the adjacent possible defines all those molecular reactions that were directly achievable in the primordial soup. Sunflowers and mosquitoes and brains exist outside that circle of possibility. The adjacent possible is a kind of shadow future, hovering on the edges of the present state of things, a map of all the ways in which the present can reinvent itself. The strange and beautiful truth about the adjacent possible is that its boundaries grow as you explore them. Each new combination opens up the possibility of other new combinations (Johnson 2010).

An explicitly historical approach to social innovation allows the observer to track the ways in which an innovative idea moves forward to link to other symbiotic ideas, particularly when faced with opposition when moving along a particular trajectory. The best example of this is found in the case of legalization of contraception. Tracing back to the 1700 s and early 1800 s, abortion, a radical form of birth control, was legal under the common law as long as the abortion was conducted before the mother could feel the fetus move. In addition, other contraceptives, primarily spermicide, were commonly prepared and used in the home to prevent unplanned pregnancies. By the early 1800 s the social demand for birth control was evident and the marketplace began to capitalize on this opportunity and birth control became available in the open market. Technological and medical advances in the mid 1800 s contributed to the commercialization of abortions and allowed for the domestic manufacturing of condoms and rubber cervical caps, each of which increased the use of birth control practices by the general public.

However, in the 1800s the increasing demand for and use of birth control spurred concerns, particularly with regard to abortions. In 1857, the American Medical Association began a crusade against abortion and petitioned for the passage of criminal abortion laws. By the end of the century, every state in the USA had restricted abortion (Tone 1996). At the same time though, public concerns revolving around the morality and right of an individual to "play God" offered public support for the American Medical Association to counter act the movement toward open access to birth control. The great "birth control controversy" began in 1873 when Anthony Comstock successfully petitioned Congress to declare contraception of all kinds "obscene." The result was the banning of the distribution of all such materials through the mail (Parry 2011). Following the "Comstock Act," many states also criminalized the circulation of contraceptive information and devices. As a result, doctors who dared to inform women about the prevention of birth through any means, including abstinence, were criminally liable.

Forced out of the market, the advocates of birth control had to find new allies. Beginning in 1910 a campaign to overturn the Comstock Act was launched by social entrepreneurs Emma Goldman, Mary Ware Dennett, and Margaret Sanger (Parry 2011). This marked the beginning of the birth control movement, associated explicitly with women's sexual liberation and gender equality, spearheaded by Margaret Sanger (Tone 1996).

Sanger insisted that women's sexual liberation and economic autonomy depended on the availability of safe, inexpensive, and effective birth control (Tone 1996), and she wasn't afraid to push 
buttons and defy the law to get her point across. In the beginning of her fight to legalize birth control, Sanger illegally published a pamphlet titled "Family Limitation." However, to avoid prosecution she fled the U.S. to Europe, to return only upon the death of Anthony Comstock.

Faced with continuous opposition, Sanger was to associate with different allies over the next 30 years, building off the venereal disease scare in WWI, the extreme poverty of the depression in the 30s, and the desire of the private sector to re-enter the market where there was clear demand. The legal opposition however continued until, in 1936 the medical director of Sanger's Birth Control Clinic Research Bureau in New York City was criminally accused of importing contraceptive materials from Japan. In a landmark case, known as U.S. vs. One Japanese Pessaries, the Supreme Court determined that birth control could no longer be declared obscene. This allowed physicians in every state to legally send and receive contraceptive devices and information through the mail for the first time since the Comstock Act was initiated in 1873 (Tone 1996).

These allies represented both their own interests (medical, social welfare, private sector) but they also represented an adjacent possible for Sanger and others who were pursuing a transformation of women's rights and freedoms. Which combinations were possible was emergent and highly contextual, but without strategic agency the agenda would not have moved forward. The adjacent possible can be seen as potentially an endogamous game changer.

What is often missing in accounts of these combinations is agency. Agency is a somewhat problematic concept in complexity theory because the notion of emergence implies a pattern evolving without intention and direction from the interaction of variables. And yet a closer look at social innovations through time reveals agents acting with intent (Westley et al. 2013). This becomes more comprehensible if we recognize the opportunistic nature of these actions: such agents are motivated by a passion for a particular goal, however they will use whatever means present themselves to try to forward these goals. This has unpredictable and emergent effects on the pathway toward transformation.

In the case of the national parks, the adjacent possible, which combined and recombined with the Romantic desire to save pristine nature, contained the colonist tendencies to extract wealth from the new lands. The close affiliation of the spread of the national parks with the colonization is well illustrated by the following example: the first international environmental conference was held in 1900 in London and was dedicated to the protection of wildlife in Africa. There were no Africans present; the delegates were from the foreign ministers of the colonial powers that then controlled the continent: France, Germany, Belgium, Italy, Spain, Portugal, and Great Britain (Guha 2000). Soon after, the first multinational conservation society was established and was called "Society for the preservation of the fauna of the Empire". With colonization the boundaries of the known world expanded and thus, the resources "beyond the frontier" were no longer viewed as unlimited (Jones 2012). It was also true that the destruction of wilderness and depletion of valuable natural resources was both most visible and most rapid in the colonies. The establishment of national parks throughout the world was an attempt "to incorporate certain forms of valued nature into schemes of national or imperial development"(Gissibl et al. 2012:8).

Although clearly this thread was in tension with the notion of preserving a pristine wilderness, history indicates that these two preoccupations, interwoven with a third, the conservation scientists desire to inventory the wilderness for new species of flora and fauna, worked together to secure the necessary political and financial resources required. After the Civil War was over, the U.S. government expressed interest in exploring natural resources available in the western territories of the country. This interest was mainly dictated by the economic hardship of the postCivil War period. By this time, it was already known that Yellowstone offered stunning scenery and could potentially become a major tourism destination. However, U.S. government was interested to see if Yellowstone could serve not merely as a tourism destination, but also as a repository of valuable natural resources. In 1871 funds were designated to support an expedition that would document what natural resources were available in the west, and particularly on the route of the transcontinental railroad that was being constructed during that period. The first transcontinental linkage that joined the tracks of the Central Pacific and Union Pacific railroads at Promontory Point, Utah, was completed two years prior to the 1871 expedition, thus paving the way to a more rapid and intensive development of the Far West (Merrill 1999). The 1871 expedition was led by Dr. Ferdinand Hayden, the head of the U.S. Geological and Geographical Survey of the Territories, and was the first scientific expedition that studied and documented the territory of the present Yellowstone National Park (Merrill 1999, McNamara 2014).

The exploration of the West and the expansion of the railway network were intertwined processes. By 1871, railroad companies became powerful empires and major land-administrating agencies. During the period of 1862-1871, Congress granted about 174 million acres of public land to construct transcontinental railroads. The Northern Pacific Railroad that aimed to build a railroad line connecting Chicago to the West Coast, actively promoted Yellowstone as a place of spectacular beauty (Merrill 1999). It is suggested that the Northern Pacific adopted Judge Kelley's suggestion of protecting Yellowstone area as a company policy and started to actively advocate for it (Haines 1996). The main financial backer of the Northern Pacific, Jay Cooke, famously publicized Yellowstone as "America's Switzerland" claiming that instead of traveling to Europe to see the beautiful natural scenery, Americans would soon travel to the West, thus urging investors to fund the western line construction. It is also believed that Northern Pacific was interested to see the results of the Hayden expedition. Given that the company paid favors to Hayden by providing cheap rates and helping with transporting horses and supplies, Hayden planned to survey the route for the possible location of the rail beds (Merrill 1999).

The expedition that Hayden led in 1871 to explore the territory of the present Yellowstone National Park was one of the largest endeavors of its kind, with the budget of $\$ 40,000$ and lasting for a few months. The team consisted of 32 people including a geologist, a topographer, a mineralogist, a zoologist, an ornithologist, an agricultural statistician, an entomologist, a physician, a support staff of drivers, waiters, cooks, general 
assistants, hunters and guides, a wagon master, a secretary, as well as a painter Thomas Moran and a photographer William Henry Jackson (McNamara 2014).

After the expedition, Hayden prepared a 500-page report for Congress with the detailed accounts on what the expedition found. In addition, Moran produced paintings of the Yellowstone scenery, while Jackson brought back the photographs (McNamara 2014). The expedition resulted in the large amount of various materials for scientific investigation, "forty-five large boxes containing more than one thousand specimens of minerals (including specimens from the hot springs), more than six hundred specimens of rocks, large numbers of mammal and bird skins, eggs, and other items had been sent during the expedition to the Smithsonian" (Merrill 1999:203)

Hayden's contribution extended beyond organizing an expedition and writing a report. After receiving a letter from the Northern Pacific with the suggestion to set aside the area of Yellowstone as a national park, he became one of the most active advocates of this idea (Merrill 1999).

The draft bill was prepared based on the Yosemite model and introduced in both houses of Congress on 18 December 1871. Hayden and his supporters actively engaged with the members of Congress by lobbying for the idea of creating a national park. With the enthusiasm, energy, and thorough knowledge of the subject, Hayden communicated to the congressmen the importance of preserving the Valley of the Upper Yellowstone. In this process, Jackson's impressive photographs and Moran's watercolors proved to be indispensable (Merrill 1999). Hayden argued that aside from the unique scenery and geological features of the area, the entire Yellowstone area would not be suitable for agricultural or mining purposes because of its altitude and geography. He called for dedicating this area "as a pleasure ground for the benefit and enjoyment of the people" and if the congress would not pass the corresponding bill, Hayden warned that "persons are now waiting for the spring to open to enter in and take possession of these remarkable curiosities, to make merchandise of these beautiful specimens, to fence in these rare wonders, so as to charge visitors a fee, as it is now done at Niagara Falls, for the sight of that which ought to be as free as the air or water" (Merrill 1999:208).

The Bill did not encounter much opposition, although there was an attempt to send it back to the Committee of Public Lands and Committee on Territories, however, the representative Henry Dawes interfered. Dawes was one of the most influential members of the House at that time, but more importantly, was a friend of Dr. Haynes and shared strong conservation convictions. Dawes spoke while commenting on the proposed legislation (Haines 1996:171):

This bill follows the analogy of the bill passed by Congress six or eight years ago, setting apart the Yosemite Valley... with this difference: that bill granted to the State of California the jurisdiction over the land beyond the control of the United States. This bill reserves the control over the land... to the United States... it will infringe upon no vested rights... treads upon no rights of the settler... and it received the urgent and ardent support of the legislature of that Territory [Montana].
The establishment of Yellowstone National Park did not unfold without opposition. The local residents of the area were against imposing strict restriction on economic development and settlements because they feared that these regulations would hinder the economic prosperity of the region. These groups advocated for the reduction of the park size and allowing mining, hunting, and logging activities. The opponents of the park were active and insistent. For example, Montana's Congressional representatives introduced bills into Congress for every season for 20 years with the suggestion to undesignate the park (Wuerthner 2007).

Thus, the establishment of the Yellowstone Park, which paved the way for all future parks, was not solely guided by altruistic motives. There was a combination of forces that triggered this development. For one thing, aside from interested individuals hoping to preserve the natural wonders, the idea of creating a national park was also lobbied by a powerful corporation, although with radically different interests. The Northern Pacific Railroad Company intended to monopolize the tourist traffic and trade corridors in this area. The fact that the huge lands would be under federal control and free of any private claims would limit competition and help the Northern Pacific to establish its monopoly across southern Montana Territory. However, in the mid-1880s Congress denounced proposals by railroad and mining companies to construct a railway through the northern part of Yellowstone and reduce the area of the park (Sellars 1997).

Last, in the case of residential schools, although there is clear evidence of the dominant power of one of the strands (colonial assimilation), as we have noted the concept of indigenous children receiving white education was part of indigenous philosophy as well. However, it seems likely that in advocating for such education, indigenous leaders were still informed by a belief that the two nations could and should coexist on an equal footing: the Treaty of Niagara. At that time, Aboriginal Peoples and early colonists had begun to establish principles for interaction that covered authority over lands and resources (Borrows 1998). Aboriginal Peoples held considerable power relative to the British colonists because of important trade relations established through the fur trade and military relations critical to subduing American expansion (Miller 2009). However, encroaching settler populations and increasing tensions signaled the need to formalize principles for interaction. The Royal Proclamation of 1763, issued by King George III, outlined protections for Crown and Aboriginal jurisdiction, stating that Aboriginal lands could not be taken up without consent and establishing clear rules for interacting with Aboriginal Peoples until the formal treaty process could be completed (Borrows 1998).

Aboriginal Peoples played an active role interpreting the Royal Proclamation through oral promises and symbolisms performed at the Treaty of Niagara in 1764 where the Royal Proclamation was affirmed by both Aboriginal Peoples and early colonists. The Treaty of Niagara marked a monumental gathering of Aboriginal Peoples, the most diverse ever recorded, and, although left with few options other than to build a relationship with the British, 2000 Chiefs made the journey to engage in the events (Borrows 1998, 2005).

Among the numerous exchanges of presents, promises, and wampum belts (a common diplomatic tool used by Aboriginal 
Peoples), perhaps the most notable exchange was that of a TwoRow Wampum Belt that represented a relationship between Aboriginal Peoples and the British Empire built on peace, friendship, and respect, and a promise to uphold the integrity of each nation by promising noninterference with each other's internal affairs (Borrows 1998, 2005). Superintendent of Indian Affairs William Johnson, husband to a Mohawk woman and highly regarded among Aboriginal Peoples, demonstrated his understanding of importance of the exchange as he presented the Wampum belt (as quoted in Borrows 1998:163):

Inow therefore present you the great Belt by which I bind all your Western Nations together with the English, and I desire that you will take fast hold of the same, and never let it slip, to which end I desire that after you have shewn this Belt to all Nations you will fix one end of it with the Chipeweighs at St. Marys [Michilimackinac] whilst the other end remains at my house...

A year after the Treaty of Niagara, Williams invoked the symbolism of the Two-Row Wampum and an understanding that the events at Niagara in 1764 did not imply sovereignty over Aboriginal Peoples when he evaluated a concerning treaty report that implied Aboriginal Peoples had been mistreated: "These people had subscribed to a Treaty with me at Niagara in August last...they can not be brought under our laws, for some Centuries..." (as quoted in Borrows 1998:164). Borrows (1998) provides evidence by way of transcripts of a meeting near Manitoulin Island in 1818 that the Royal Proclamation and Two Row Wampum were actively used to shape relationships between Aboriginal Peoples and the British Crown over 50 years after the gathering; the transcripts state that an Anishanaabe speaker took out the original Two Row Wampum presented at the Treaty of Niagara and stated the following:

Father, This my ancestors received from our Father, Sir W. Johnson. You sent word to all your red children to assemble at the crooked place (Niagara)... You then laid this belt on a mat, and said - may all be brethren united, and hope our friendship will never cease. I will call you my children; will send warmth (presents) to your country; and your families shall never be in want. (as quoted in Borrows 1998:166)

Viewed from the long view of historical perspective, one can see that the "big teaching wigwam" did not refer to the assimilation of indigenous children but to the creation of an opportunity for mutual learning, and opportunity that was not realized in the residential schools. It did not, however, disappear. In June 2008, Stephen Harper, the then Prime Minister of Canada, issued an apology for the damage done by Residential Schools. He closed that speech in the following way:

The burden of this experience has been on your shoulders for far too long. The burden is properly ours as a government, and as a country.

There is no place in Canada for the attitudes that inspired the Indian residential schools system to ever again prevail.

You have been working on recovering from this experience for a long time and in a very real sense, we are now joining you on this journey.
The government of Canada sincerely apologizes and asks the forgiveness of the aboriginal peoples of this country for failing them so profoundly.

We are sorry.

In moving towards healing, reconciliation and resolution of the sad legacy of Indian residential schools, implementation of the Indian Residential Schools Settlement agreement began on September 19, 2007.

Years of work by survivors, communities, and aboriginal organizations culminated in an agreement that gives us a new beginning and an opportunity to move forward together in partnership.

A cornerstone of the settlement agreement is the Indian Residential Schools Truth and Reconciliation Commission. This commission presents a unique opportunity to educate all Canadians on the Indian residential schools system.

It will be a positive step in forging a new relationship between aboriginal peoples and other Canadians, a relationship based on the knowledge of our shared history, a respect for each other and a desire to move forward together with a renewed understanding that strong families, strong communities and vibrant cultures and traditions will contribute to a stronger Canada for all of us.

The apology recognized the need for some redirection of resources and authority, based on a different definition, one of partnership, not assimilation, and a new conversation (truth and reconciliation). This recognition was long overdue and had been preceded by a number of changes on a legislative front. It was also not new. Arthur (2009) explains that there are rarely ever any truly novel technological innovations, that they have an ancestry and arise as combinations and recombinations of previously existing technologies.

Applying this reasoning to social phenomenon, it resonates with the path-dependent nature of assimilation policy described above. However, Arthur's views leave little room for the re-emergence of old, or even ancient, ideas and knowledge to fill social needs. For instance, there is little to no novelty flowing from the notion of a co-operative relationship between Aboriginal and nonAboriginal Peoples in Canada, it is an old idea formalized through the Royal Proclamation and several early Treaties negotiated through Wampum diplomacy. Further still, the wisdom underlying this relationship is ancient and held to this day by indigenous knowledge guardians. Therefore, this "new" approach to aboriginal relationships must be viewed as having novelty in context; it is merely the context that is novel, not the underlying social phenomenon. Its reappearance, however, in a speech from Canada's highest elected official, was a welcome reassertion of a long neglected element which, although it had never dominated the residential school initiative, was still part of indigenous heritage associated with relations to white colonialists.

\section{SUMMARY AND CONCLUSIONS}

Looking across these three historical cases of social innovation we see how the concept of game changer associated with socially constructed opportunities helps to explain the dynamics of transformation over time. We have seen that game changers appear to be of three kinds: 
- Seminal: corresponding to Brian Arthur's scientific discovery of new phenomena, which catalyzes a whole new game, a stream of innovations that combine and recombine in the form of new technologies. In our cases, and perhaps in many cases of social innovation, these phenomena are less often breakthroughs in our understanding of the nature of the natural and physical world and more often in the nature of radically new ideas or philosophies, what Durkheim would call "social facts."

- Exogenous: events that affect large numbers of people and create a critical transition in the development of innovations in multiple regimes/problem domains. These events act as shocks to disrupt patterns and offer opportunities for new trajectories associated with the social innovation.

- Endogamous: associations and combinations that occur in direct relationship/response to an innovation unfolding in a problem domain. It is at this scale that we see the game changing aspect of conflict, political opposition, or resource scarcity. This can be an opposing idea that gains the status of a law or the opportunity for an alliance with a stream of activity/meaning that is proximate (adjacent possible) but distinctive.

The cases thus analyzed highlight the role of agency through time, as each of these categories of opportunity required the active sense making or meaning construction on the part of a variety of agents. In the case of seminal game changers, social and political philosophers were involved the prolonged and sustained creation of new social and political ideas. Once these ideas were published and became part of the zeitgeist of their time, social innovators used these ideas to leverage the more concrete initiatives described in these cases. Initially, these were niche strategies, where programs, platforms, or projects were protected and nurtured (Seyfang and Haxeltine 2012, Smith and Raven 2012), but they then began to spread. Secondly, exogenous game changers come in the form of shocks, such as the international conflicts of the World Wars. These represented opportunities for further defining and elaborating the social innovations, and were dependent on the intense or elaborated sense-making of actors involved either directly in the innovation (as in the case of the National Parks) or in adjacent problem domains (as in the case of the legalization of contraception). We can see, too that the form of response linking the innovation to the exogenous opportunity depended in part on the stage of the innovation (the parks, having been established, used the opportunity to further consolidate and safeguard their privilege), or in the current political reality of opposition, as in the need to find new partnerships in the face of the Comstock Act, which heightened the importance of the venereal disease epidemics for agents advocating for legalization of birth control. Last, responses to endogamous opportunities are dependent on the presence of political/strategic allies and adversaries; faced with opposition or resource scarcity, these cases indicate that agents will search for partnerships to enhance their own limited capacities. This finding supports the increasing recognition of the role of politics and power in understanding social change (Smith and Stirling 2010, Geels 2014)

This work has some interesting lessons for scholars and practitioners of social innovation working today. First, these cases show a clear pattern of bricolage. Like technological innovation these social innovations progress through combination and recombination.

However, unlike the technological bricolage described by Arthur (2009), in these social innovation cases the bricolage seems to be driven as much by scarcity as by opportunity. Over time social innovations take on new elements through taking on new partners in order to survive. Understanding this history helps to explain Hampden-Turner's (1990) claim that most problem domains are bounded by paradoxes, and that ongoing innovation is an attempt to reconcile those paradoxes. At any point in time, the innovators described in this paper deliberately and strategically engaged a number of separate and sometimes unusual partners for resource reasons. In doing so they at times associated the evolving innovation with unusual even controversial elements that were grafted on to the innovation. The inherent paradox at times created then becomes definitive, structuring future conflicts and debates (such as the struggles over nature as pristine wilderness vs. rich resource). Once engaged, these different elements remain a part of the social debates that surround these difficult issues, threatening always to pull the innovation toward one basin of attraction vs. another, what Hampden Turner (1990) terms the "horns of the dilemma." Social innovations remain dynamic and potentially volatile combinations of ideas and rarely achieve stasis. It is for this reason that ethical vigilance is crucial.

Finally, looking forward, it becomes clear that sustained social innovations such as the three described here, whether ultimately viewed as positively or negatively transformative, becomes a powerful adjacent possible, an endogamous game changer for the other social innovations. Hence, establishing a National Park System enshrined in law became in Giddens's (1984) terms "a structure of legitimation," providing an opening for such innovative legislation as the Endangered Species Act, which when passed, almost surreptitiously in the U.S., in 1973 has had profound impacts on development in the U.S., and for a variety of innovative programs and processes to conserve endangered species and even reintroduce them to the wild (Westley and Miller 2003). Similarly the legalization of contraception, which has legitimized the woman's right to control her reproductive processes, has opened the door to new reproductive technologies, driven by market demand that in turn is attracting a new round of ethical, religious, and moral debate. Finally, despite and even because of its pernicious and destructive effects, the residential schools have changed the conversation in Canada about indigenous rights, providing for new ways of looking at the relationship between colonizers and indigenous peoples and opening the door for the current initiatives on reconciliation and indigenous opportunity. This has confirmed to us the importance of the historical perspective; it allows the recognition that social innovation is a dynamic, successful cycle producing both good and bad transformative elements, and providing opportunities for a new cycle in an adjacent possible domain.

Responses to this article can be read online at: http://www.ecologyandsociety.org/issues/responses. $\mathrm{php} / 8811$ 


\section{LITERATURE CITED}

Arthur, W. B. 2009. The nature of technology: what it is and how it evolves. Free Press, New York, New York, USA.

Avelino, F., J. Wittmayer, A. Haxeltine, R. Kemp, T. O'Riordan, P. Weaver, D. Loorbach, and J. Rotmans. 2014. Game changers and transformative social innovation: the case of the economic crisis and the new economy. TRANSIT working paper \#1. EU SSH.2013.3.2-1 Grant agreement no: 613169. TRANSIT, Rotterdam, The Netherlands. [online] URL: http://www. transitsocialinnovation.eu/resource-hub/game-changers-andtransformative-social-innovation-the-case-of-the-economic-crisisand-the-new-economy-1

Becker, M. C., T. Knudsen, and J. G. March. 2006. Schumpeter, Winter, and the sources of novelty. Industrial and Corporate Change 15:353-371. http://dx.doi.org/10.1093/icc/dt1003

Biggs, R., F. R. Westley, and S. R. Carpenter. 2010. Navigating the back loop: fostering social innovation and transformation in ecosystem management. Ecology and Society 15(2):9. [online] URL: http://www.ecologyandsociety.org/vol15/iss2/art9/

Borrows, J. 1998. Wampum at Niagara: The Royal Proclamation, Canadian legal history and self-government. Pages 155- 172 in M. Asch, editor. Aboriginal and treaty rights in Canada: essays on law, equality and respect for difference. UBC Press, Vancouver, British Columbia, Canada.

Borrows, J. 2005. Crown and aboriginal occupations of land: a history \& comparison. Ipperwash Inquiry, Toronto, Ontario, Canada.

Brown, R. R, M. A. Farrelly, and D. A. Loorbach. 2013. Actors working the institutions in sustainability transitions: the case of Melbourne's stormwater management. Global Environmental Change 23(4):701-718. http://dx.doi.org/10.1016/j.gloenvcha.2013.02.013

Byrne, D. S. 1998. Complexity theory and the social sciences: an introduction. Routledge, London, UK.

Castellano, M. B., L. Archibald and M. DeGagné. 2008. From truth to reconciliation: transforming the legacy of residential schools. Aboriginal Healing Foundation, Ottawa, Ontario, Canada.

Chapman, W. 2014. Hawai'i, the military, and the national park: World War II and its impacts on culture and the environment. National Park Service, Washington, D.C., USA. [online] URL: http://www.nps.gov/hale/historyculture/upload/WWII-Special-HistoryHawaii-FINAL-REPORT-7-16-14-a.pdf

De Haan, J., and R. Rotmans. 2011. Patterns in transitions: understanding complex chains of change. Technological Forecasting \& Social Change 78(1):90-102. http://dx.doi. org/10.1016/j.techfore.2010.10.008

Dorado, S. 2005. Institutional entrepreneurship, partaking, and convening. Organization Studies 26(3):383-414. http://dx.doi. org/10.1177/0170840605050873

Duncan, D. 2009. The National Parks. America's best idea. An illustrated history. Alfred A. Knopf, New York, New York, USA.

Durkheim, E. 1912, 1968. Les formes elementaires de la vie religious. Fifth Edition. Presse Universitaires de France, Paris, France.
European Commission. 2013. Social innovation research in the European Union: approaches, findings and future directions. European Commission, Brussels, Belgium. [online] URL: http:// www.gppq.pt/h2020/docs/brochuras/society/social innovation $\%$ 20in $\% 20$ the $\% 20$ eu.pdf

Geels, F. W. 2014. Regime resistance against low-carbon transitions: introducing politics and power into the multi-level perspective. Theory, Culture \& Society 31(5):21-40. http://dx.doi. org/10.1177/0263276414531627

Geels, F. W., and J. Schot. 2007. Typology of sociotechnical transition pathways. Research Policy 36:399-417. http://dx.doi. org/10.1016/j.respol.2007.01.003

Gelcich, S., T. P. Hughes, P. Olsson, C. Folke, O. Defeo, M. Fernández, S. Foale, L. H. Gunderson, C. Rodríguez-Sickert., M. Scheffer, R. S. Steneck, and J. C. Castilla. 2010. Navigating transformations in governance of Chilean marine coastal resources. Proceedings of the National Academy of Sciences 107 (39):16794-16799. http://dx.doi.org/10.1073/pnas.1012021107

Giddens, A. 1984. The constitution of society. Polity, Cambridge, UK.

Gissibl, B., S. Höhler, and P. Kupper. 2012. Introduction. Towards a global history of national parks. Pages 1-27 in B. Gissibl, S. Höhler, and P. Kupper, editors. Civilizing nature: national parks in global historical perspective. Berghahn Books, New York, New York, USA.

Grin, J., J. Rotmans, and J. Schot. 2010. Transitions to sustainable development; new directions in the study of long term transformative change. Routledge, New York, New York, USA.

Guha, R. 2000. Environmentalism: a global history. Longman, New York, New York, USA.

Haig-Brown, C. 1988. Resistance and renewal: surviving the Indian residential school. Tillacum Library, Vancouver, British Columbia, Canada.

Haines, A. 1996. The Yellowstone story: a history of our first national park. Yellowstone Association for Natural Science, History \& Education, Yellowstone National Park, Wyoming, USA.

Hampden-Turner, C. 1990. Charting the corporate mind. Free Press, New York, New York, USA.

Homer-Dixon, T. 1996. Strategies for studying causation in complex ecological-political systems. Journal of Environment and Development 5(2):132-148. http://dx.doi.org/10.1177/107049659600500202

Howaldt, J., A. Butzin, D. Domanski, and C. Kaletka. 2014. Theoretical approaches to social innovation: a critical literature review. A deliverable of the project: "Social Innovation: Driving Force of Social Change" (SI-DRIVE). Sozialforschungsstelle, Dortmund, Germany.

Jarman, T. J. 1951. Landmarks in the history of education: English education as part of the European tradition. John Murray, London, UK.

Johnson, S. 2010. Where good ideas come from: the natural history of innovation. Penguin, New York, New York, USA. 
Jones, K. 2012. Unpacking Yellowstone. The American national park in global perspective. Pages 31-49 in B. Gissibl, S. Höhler, and P. Kupper, editors. Civilizing nature: national parks in global historical perspective. Berghahn Books, New York, New York, USA.

Kauffman, S. 2000. Investigations. Oxford University Press, Oxford, UK.

Kemp, R., D. Loorbach, and J. Rotmans. 2007. Transition management as a model for managing processes of co-evolution towards sustainable development. International Journal of Sustainable Development \& World Ecology 14(1):78-91. http://dx. doi.org/10.1080/13504500709469709

Loorbach, D. 2010. Transition management for sustainable development: a prescriptive, complexity-based governance framework. Governance 23(1):161-183. http://dx.doi.org/10.1111/ j.1468-0491.2009.01471.x

Markard, J., R. Raven, and B. Truffler. 2012. Sustainability transitions: an emerging field of research and its prospects. Research Policy 41(6):955-967. http://dx.doi.org/10.1016/j. respol.2012.02.013

McNamara, R. 2014. First national park resulted from the Yellowstone expedition: magnificent wilderness was set aside to be protected and preserved. About.com, New York, New York, USA. [online] URL: http://history1800s.about.com/od/thegildedage/a/ first-national-park.htm

Merrill, M. D., editor. 1999. Yellowstone and the Great West: journals, letters, and images from the 1871 Hayden Expedition. University of Nebraska Press, Lincoln, Nebraska, USA.

Miles, J. C. 1995. Guardians of the parks. A history of the national parks and conservation association. Taylor \& Francis, Washington, D.C., USA.

Miller, J. R. 1990. Owen Glendower, Hotspur, and Canadian Indian Policy. Ethnohistory 37(4):386-415. http://dx.doi. org/10.2307/482861

Miller, J. R. 1996. Shingwauk's vision: a history of Native residential schools. University of Toronto Press, Toronto, Ontario, Canada.

Miller, J. R. 2009. Compact, contract, covenant: Aboriginal treatymaking in Canada. University of Toronto Press, Toronto, Ontario, Canada.

Moore, M.-L., D. J. Riddell, and D. Vocisano. 2015. Scaling out, scaling up, scaling deep: strategies of non-profits in advancing systemic social innovation. Journal of Corporate Citizenship 58:67-84. http://dx.doi.org/10.9774/GLEAF.4700.2015.ju.00009

Mumford, M. D., and P. Moert1. 2003. Cases of social innovation: lessons from two innovations in the 20th century. Creativity Research Journal 15(2-3):261-266. http://dx.doi.org/10.1080/104$\underline{00419.2003 .9651418}$

Nicholls, A., J. Simon, and M. Gabriel. 2015. Introduction: dimensions of social innovation. Pages 1-26 in A. Nicholls, J. Simon, and M. Gabriel, editors. New frontiers of social innovation research. Palgrave MacMillan, London, UK. http://dx.doi. org/10.1057/9781137506801 1
Olsson, P., L. H. Gunderson, S. R. Carpenter, P. Ryan, L. Lebel, C. Folke, and C. S. Holling. 2006. Shooting the rapids: navigating transitions to adaptive governance of social-ecological systems. Ecology and Society 11(1):18. [online] URL: http://www. ecologyandsociety.org/vol11/iss1/art18/

Parry, M. 2011. "Pictures with a purpose": the birth control debate on the big screen. Journal of Women's History 23 (4):108-130. http://dx.doi.org/10.1353/jowh.2011.0044

Phillips, M. 2004. The ascent of woman: a history of the suffragette movement. Abacus, London, UK.

Plummer, R. and D. Fennell. 2007. Exploring co-management theory: prospects for sociobiology and reciprocal altruism. Journal of Environmental Management 85(4):944-955. http://dx. doi.org/10.1016/j.jenvman.2006.11.003

Raven, R., J. Schot, and F. Berkhout. 2012. Space and scale in socio-technical transitions. Environmental Innovation and Societal Transitions 4:63-78. http://dx.doi.org/10.1016/j.eist.2012.08.001

Rotmans, J., and D. Loorbach. 2010. Towards a better understanding of transitions and their governance: a systematic and reflexive approach. Pages 105-222 in J. Grin, J. Rotmans, and J. Schot, editors. Transitions to sustainable development: new directions in the study of long term transformative change. Routledge, New York, New York, USA.

Scheffer, M., J. Bascompte, W. A. Brock, V. Brovkin, S. R. Carpenter, V. Dakos, H. Held, E. H. Van Nes, M. Rietkerk, and G. Sugihara. 2009. Early-warning signals for critical transitions. Nature 461(7260):53-59. http://dx.doi.org/10.1038/nature08227

Sellars, R. W. 1997. Preserving nature in the national parks. A history. Yale University Press, New Haven, Connecticut, USA.

Seyfang, G., and A. Haxeltine. 2012. Growing grassroots innovations: exploring the role of community-based initiatives in governing sustainable energy transitions. Environment and Planning C: Government and Policy 30:381-400. http://dx.doi. org/10.1068/c10222

Smith, A., and R. Raven. 2012. What is protective space? Reconsidering niches in transitions to sustainability. Research Policy 41(6):1025-1036. http://dx.doi.org/10.1016/j.respol.2011.12.012

Smith, A., and A. Stirling. 2010. The politics of social-ecological resilience and sustainable socio-technical transitions. Ecology and Society 15(1):11. [online] URL: http://www.ecologyandsociety. org/vol15/iss1/art11/

Spring, J. 2008. The American school: from the Puritans to no child left behind Seventh Edition. McGraw-Hill, Boston, Massachusetts, USA.

Thagard, P. 2012. Creative combination of representation: scientific discovery and technological invention. Pages 389-405 in R. W. Proctor and E. J. Capaldi, editors. Psychology of science: implicit and explicit processes. Oxford University Press, Oxford, UK. http://dx.doi.org/10.1093/acprof:oso/9780199753628.003.0016

Tilley, C. 2008. Explaining social processes. Paradigm, Boulder, Colorado, USA. 
Tone, A. 1996. Contraceptive consumers: gender and the political economy of birth control in the 1930s. Journal of Social History 29(3):485-506. http://dx.doi.org/10.1353/jsh/29.3.485

Van den Ende, J., and R. Kemp. 1999. Technological transformations in history: how the computer regime grew out of existing computing regimes. Research Policy 28(8):833-851. http:// dx.doi.org/10.1016/s0048-7333(99)00027-x

Van Wingerden, S. A. 1999. The women's suffrage movement in Britain, 1886-1928. MacMillan, Basingstoke, Hampshire, UK. http://dx.doi.org/10.1007/978-1-349-27493-2

Walker, B., and J. A. Meyers. 2004. Thresholds in ecological and social-ecological systems: a developing database. Ecology and Society 9(2):3. [online] URL: http://www.ecologyandsociety.org/ vol9/iss $2 / \operatorname{art} 3 /$

Westley, F. R., and P. S. Miller, editors. 2003. Experiments in consilience. Island Press, Washington, D.C., USA.

Westley, F. R., O. Tjornbo, L. Schultz, P. Olsson, C. Folke, B. Crona, and Ö. Bodin. 2013. A theory of transformative agency in linked social-ecological systems. Ecology and Society 18(3):27. http://dx.doi.org/10.5751/es-05072-180327

Westley, F. R., B. Zimmerman, and M. Quinn Patton. 2006. Getting to maybe: how the world is changed. Random House, Toronto, Ontario, Canada.

Wuerthner, G. 2007. NREPA: Local interests and conservation history. New West, 15 November. [online] URL: http://newwest. net/topic/article/nrepa_local_interests_and_conservation_history/ C38/L38/

Young, O., E. F. Lambin, F. Alcock, H. Haberl, S. I. Karlsson, W. J. McConnell, T. Myint, C. Pahl-Wostl, C. Polsky, P. S. Ramakrishnan, H. Schroeder, M. Scouvart, and P. H. Verburg. 2006. A portfolio approach to analyzing complex humanenvironment interactions: institutions and land change. Ecology and Society 11(2):31. [online] URL: http://www.ecologyandsociety. org/vol11/iss2/art31/ 